\title{
Profile and Behaviour of Mother as Factor of Increasing Diarrhea Incidence Children Under Five at Jatinangor District in 2013
}

\author{
Rahayu Widhyasti, ${ }^{1}$ Nita Arisanti, ${ }^{2}$ Ina Rosalina ${ }^{3}$ \\ ${ }^{1}$ Faculty of Medicine Universitas Padjadjaran, ${ }^{2}$ Department of Public Health Faculty of \\ Medicine, Universitas Padjadjaran, ${ }^{3}$ Department of Child Health Faculty of Medicine Universitas \\ Padjadjaran/Dr. Hasan Sadikin General Hospital Bandung
}

\begin{abstract}
Background: In 2012, data from Health Center of Jatinangor District showed nearly 50\% of diarrhea cases occured in children under five at Sayang Village and Cilayung Village. Diarrhea cannot be separated from several factors that influence it, thus to reduce the incidence rate of diarrhea needs description of factors that affect diarrhea in children so that prevention can be done maximally. Objective of this study was to describe profile and behavior of mother as one factor of increasing diarrhea incidence in children under five at Jatinangor.
\end{abstract}

Methods: This study was descriptive with cross-sectional design conducted at Sayang Village and Cilayung Village in October-November 2013. The respondents of this study were 102 mothers who have infants aged 0-59 months thorough cluster sampling methods. Respondent will be interviewed and given validated questionnaire.

Results: The result showed that $57.8 \%$ of mother aged $25-35$ years, mostly graduated from junior high education (41.2\%), and $81.4 \%$ as a housewife. Most of diarrhea occurred in children under 2 years and female. There were $73.5 \%$ mother who exclusively breastfed, $94.1 \%$ have good behavior of clean water usage, $61.8 \%$ with good hand washing behavior, and $60.8 \%$ respondents utilized healthy latrine.

Conclusions: This study showed good results in behaviour of exclusive breastfeeding, behavior of clean water usage, behaviour of hand washing with clean and water flow, and behaviour of healthy latrine usage. Other factors might be contributed to increasing diarrhea incidence. [AMJ.2016;3(4):655-9]

Keywords: Children under five, diarrhea incidence, maternal factor

\section{Introduction}

Nowadays, in the globalization era, diarrhea becomes one of the main factor in child mortality. The incidence of diarrhea has been recorded as the highest mortality level and contributed to higher morbidity rate in Indonesia. In developing country as Indonesia, the incidence of diarrhea has been registered as one of public health problems which need a biggest attention. The subsector of Diarrhea, Ministry of Health Republic of Indonesia recorded data from 2000 to 2010 noted that there were trends of increasing incidence of diarrhea. ${ }^{1}$

The main factor that frequently involved in diarrhea incidence are mother and environmental factors. The breast feeding behavior factors from mothers have been investigated as the highest risk that caused diarrhea incidence followed by poor water and poor sanitation condition. Another factor that also involves in diarrhea incidence is poor water-sanitation system and lack of standardized latrines. ${ }^{1}$

The diarrhea incidence about $13 \%$ that had been recorded occurred more frequently in rural area compared to urban area. Moreover, this number is higher in the lower education and lower income level. ${ }^{2}$ Jatinangor has a high level of diarrhea incidence. In order to decrease and eliminate the diarrhea, several informations and data of risk factors in children are highly needed. The study's objective was to find factors related to the incidence of diarrhea in children under five at Jatinangor District.

Correspondence: Rahayu Widhyasti, Faculty of Medicine, Universitas Padjadjaran, Jalan Raya Bandung-Sumedang Km.21, Jatinangor, Sumedang, Indonesia, Phone: +62 87821403330 Email: rahayu.widhyasti@gmail.com 


\section{Methods}

This study was conducted from October to November 2013 in District Jatinangor, West Java, Indonesia, specifically in Sayang Village and Cilayung Village with cross-sectional method. This study was approved by Public Health Ethics Commitee Faculty of Medicine, Universitas Padjadjaran.

This data was taken from 102 respondents,mothers who have children with diarrhea, in Sayang Village and Cilayung Village used as subject. From the sampling frame, the respondents was included to the study by sampling and Posyandu cluster. Then, mothers with children under five fulfilling the inclusion criteria became the respondents. Hereinafter, the respondents were interviewed about incidence of diarrhea and given questionnaires validated based on observation conditions.

Presentation of data were showed by a frequency distribution table about behaviour of exclusive breastfeeding, behaviour of clean water usage, behaviour of hand washing with clean \& water flow, and behaviour of healthy latrine usage.

The practice of clean water usage was assessed according to three aspects; (1) all of the source assumed to be the source of clean water, (2) drinking water process, and (3) place of storage water. ${ }^{9,14}$ The practice of good hand washing is when respondents wash their hands at least three times when their hands are dirty,i.e, (1) before eating, (2) before taking care of the child, and (3) after defecation. ${ }^{11}$ The good behaviour of clean and healthy latrine utilized were if respondents used latrines to dispose of feces daily, latrine and sources of water were within 10 meters, and cleaned up the latrine at least once in a week. ${ }^{2}$

\section{Results}

The result was obtained from mother characteristics, mostly aged 25 to 35 years $(57.8 \%)$. Most respondents have low education level. They only complete their junior high. Based on respondents occupation, $81.4 \%$ are housewives. Characteristic children of diarrhea are $58.4 \%$ occured in children aged less than or equal to 2 years and $52.9 \%$ of respondents were girls with diarrhea. The result showed that $73.5 \%$ respondents had exclusively breastfed (Table 1 ).

From practice of clean water usage, it was obtained $94.1 \%$ of the respondents that had good behaviour and only $5.9 \%$ were bad. All of these hand washing techniques must be under flowing water and use a soap. The result from this study obtained $61.8 \%$ that have good hand washing behaviour and $38.2 \%$ behave badly. As much as $60.8 \%$ respondents were included in the category of healthy latrine usage behaviour while $39.2 \%$ were still not in good behaviour.

In Jatinangor District, most respondents have already given exclusive breastfeeding to their children. Exclusive breastfeeding was viewed from two aspects, i.e. whether children were breastfed for 6 months or not and whether breastfeeding for 6 months were given additional food intake or not (Table 2).

Seen from source of water, water processing method, and storage of drinking water, most respondents were included in good behaviour (Table 3).

From the result of this study, behavior of hand washing with clean and water flow showed more than $50 \%$ in good behaviour. Washing hands were conducted before eating, before treating a child, and after defecation with soap and under water flow (Table 4).

Having a latrine at home and using it for defecation with distance of latrine with water source 10 meters and cleaning the latrine at least once in a week has been already owned by most of the respondents (Table 5).

\section{Discussion}

The study was conducted by 102 respondents and the results showed description of factors that influence the diarrhea incidence in children under five at sub Jatinangor. Based on the characteristics of the mothers and their education level, it was showed that $41.2 \%$ had passed the 9 -year basic education, although $15.7 \%$ of $21.6 \%$ just graduated from elementary school and the rest $5.9 \%$ did not complete elementary school. The higher the education level, the higher the level of knowledge especially in the field of health and also the ability to develop the information that has been obtained from the education. Based on researched by Kasman,it was mentioned that there is significant correlation between the level of knowledge from the mother with diarrhea. $^{3}$

On the results of the study, there were $81.4 \%$ of respondents as a housewife. Diarrhea in the bulletin issued by the Ministry of Health, explained that $8.7 \%$ of women who are not working or housewives tend to have a higher frequency of diarrhea than those who have occupation. ${ }^{4}$ It is assumed that mothers have job outside the house are more aware 
Table 1 Characteristic of Respondents

\begin{tabular}{|c|c|c|}
\hline Characteristic & Frequency & $\%$ \\
\hline Age of respondents & 27 & 26.5 \\
\hline Less than 25 years & 59 & 57.8 \\
\hline 25 to 35 years & 16 & 15.7 \\
\hline \multicolumn{3}{|l|}{ More than 35 years } \\
\hline Education Level & 6 & 5.9 \\
\hline Ungraduated elementary school & 16 & 15.7 \\
\hline Elementary school & 42 & 41.2 \\
\hline Junior high school & 31 & 30.4 \\
\hline Senior high school & 7 & 6.9 \\
\hline \multicolumn{3}{|l|}{ Scholar } \\
\hline Occupation & 1 & 1.0 \\
\hline Public servants & 7 & 6.9 \\
\hline Employee & 2 & 2.0 \\
\hline Labor & 1 & 1.0 \\
\hline Farmer & 8 & 7.8 \\
\hline Entrepreneur & 83 & 81.4 \\
\hline \multicolumn{3}{|l|}{ Housewife } \\
\hline Age of children & 30 & 29.4 \\
\hline $1-12$ months & 30 & 29.4 \\
\hline 13-24 months & 26 & 25.5 \\
\hline 25-36 months & 12 & 11.8 \\
\hline $37-48$ months & 4 & 3.9 \\
\hline \multicolumn{3}{|l|}{ 49-59 months } \\
\hline Gender of children & 48 & 47.1 \\
\hline Boy & 54 & 52.9 \\
\hline Girl & 100.0 & \\
\hline Total & 102 & 100.0 \\
\hline
\end{tabular}

and familiar with the health information, particularly about diarrhea. ${ }^{5}$

In the terms of the toddler characteristic, $58.4 \%$ aged under 2 years most commonly got diarrhea. Based on report that presented by Directorate General of Communicable Disease Control and Environmental Health, first 2 years of life more frequently suffered diarrhea compared to age 2 to 5 years. It was caused infants that are more susceptible exposed to feces containing bacteria and direct contact with human feces during crawling. There were $52.9 \%$ girls had it. It means that there were girls who were more susceptible to diarrhea than boys. ${ }^{4}$
Exclusive breastfeeding is one of mother's behavior that can lead to diarrhea. Exclusive breastfeeding is a natural food that suits the baby's digestive system. In addition, breastfeed can replace baby immune protection. ${ }^{6}$ Based on the study, $94.1 \%$ of respondents had breastfed and $73.5 \%$ respondents actually gave exclusive breastfed. Jatinangor District had good feeding behavior. Contrasted to the significant relationship that the diarrhea incidence affected by exclusive breastfeeding, the child whom exclusively breastfed had lower odds of diarrhea than children who are not exclusively breastfed. ${ }^{7}$ The difference may be due to the lack of mother's knowledge that 
Table 2 Behaviour of Exclusive Breastfeeding

\begin{tabular}{lcc}
\hline & Frequency & \% \\
\hline Exclusively Breastfed & 75 & 73.5 \\
Not Exclusively Breastfed & 27 & 26.5 \\
Total & 102 & 100.0 \\
\hline
\end{tabular}

Table 3 Behavior of Healthy Water Usage

\begin{tabular}{lcc}
\hline \multicolumn{1}{c}{ Behavior of Healthy Water Usage } & Frequency & \% \\
\hline Good & 96 & 94.1 \\
Bad & 6 & 5.9 \\
Total & 102 & 100.0 \\
\hline
\end{tabular}

terminate breastfeeding when the mother is sick. Based on that condition, terminating breastfeeds when a mother gets sick can lead lack of nutrition and immunity which gained from ASI. 8

Based on WHO Jounal, clean water source that has been processed and screened can reduce mortality due to infection in general and enteric bacteria. ${ }^{17}$ Based on the results from wells pump water sources and the springs have the same percentage are $38.2 \%$. If the terms of drinking water process, $96.1 \%$ of respondents have boiled water before using, and $98 \%$ use a sealed container for storage. So, it was concluded that $94.1 \%$ was included in the category of good clean water usage behavior because the water was cooked in advance and kept in covered container, while the remaining $5.9 \%$ was still quite poor. Study of Basic Human Services (BHS), the study of household drinking water process, explained that although $47.5 \%$ still contain bacteria
Escherichia coli, 99.2\% have been boiled before cooking or used. ${ }^{9}$ This difference may be based on this study only assessed from a questionnaire given to the respondents and did not directly assess the quality of water in the form of physical features such as the water's colorless, odorless, and tasteless ; water should be free of elements that can be dangerous for health such as arsenic cyanide and lead; microbiological elements examination of the water seen the appearance or absence of the pathogens that can cause illness. ${ }^{10}$ This study might be affected by these factors .

Factor that cause diarrhea according to the behavioral factors is hand washing. Based on this study, $61.8 \%$ respondents who have children suffering from diarrhea have conducted a good hand washing behavior, and the remaining $38.2 \%$ were still bad in conducting hand washing. Other factors, including trigger malabsorption diarrhea factors, food intake \& food processing factors,

Table 4 Behavior of Hand Washing with Clean and Water flow

\begin{tabular}{lcc}
\hline $\begin{array}{c}\text { Behavior of Hand Washing with Clean } \\
\text { and Water flow }\end{array}$ & Frequency & \% \\
\hline Good & 63 & 61.8 \\
Bad & 39 & 38.2 \\
Total & 102 & 100.0 \\
\hline
\end{tabular}

Table 5 Behavior of Healthy Latrine Usage

\begin{tabular}{lcc}
\hline \multicolumn{1}{c}{ Behaviour of Healthy Latrine Usage } & Frequency & $\mathbf{\%}$ \\
\hline Good & 62 & 60.8 \\
Bad & 40 & 39.2 \\
Total & 102 & 100.0 \\
\hline
\end{tabular}


and psychological factors may influence incidence of diarrhea.

Fecal-oral contact is the one of the way on how diarrhea spread in children. Stool that is not managed properly can pollute the water and the surrounding environment, so that using latrines to dispose feces daily is one form of preventing diarrhea. At least a good latrine is the one with distance of 10 meters away from the water and it aims to reduce environmental pollution and desecration of the surrounding. ${ }^{11}$ Of the study's result, $1 \%$ of respondents were still using the river to defecate, while 99\% were using latrines/ toilets. The distance of the latrines with water source is more than 10 meter as much as $77.5 \%$ and $22.5 \%$ are less than 10 meters. There were $77.5 \%$ of respondents cleaned the toilet at least 4 times a month. According to the three things above, $60.8 \%$ had good behaviour of latrine usage. Based on researched by Fandiarta AR, condition of family latrines and diarrhea incidence were not significantly influenced, $p$ value $>0: 05(p=0.581){ }^{12}$

Environmental and behavioral factors were related to diarrhea. Thoses factors are interacted each other. Diarrhea can occur if guided by environmental factors and healthy behavior. $^{13}$ If intervention of clean water, defecate disposal facilities manufacture, and behavioral of hand washing is improved, the incidence of diarrhea can be decreased significantly. ${ }^{14}$ Similarly, the behavior of exclusive breastfeeding, in early giving and at least 4-6 months will help to prevent the baby from diseases. It was caused colostrum and breastmilk containing antibodies. ${ }^{15}$

For environmental factors, clean water facilities, sanitation, latrine, sewerage, housing conditions, and bacteriological factors are highly involved the incidence of diarrhea. Bacteria E. Coli contamination is suspected as the primary cause of the fresh water consumed by the public which indicates the existence of human fecal contamination. Besides that, contamination is derived from the extraction and use of groundwater as a main source and river water also. ${ }^{16}$ Therefore, the incidence of diarrhea occurs in the presences of behavioral and environmental factors.

The limitation of this study is the lack of time so that this study is unable to perform the observation optimally. From the discussion above, the incidence of diarrhea in children under five in Jatinangor District is still high although the results of this study showed good results in behaviour of exclusive breastfeeding, behavior of clean water usage, behavior of hand washing cleanly and under water flow, and behaviour of healthy latrine usage. It can be caused by other factors that are not examined in this study.

\section{References}

1. Agtini MD. Morbiditas dan mortalitas diare pada balita di Indonesia. Buletin Jendela Data dan Informasi Kesehatan.2011:2(2):26-32.

2. Badan Penelitian dan Pengembangan Kesehatan Kementrian Kesehatan Republik Indonesia. Riset Kesehatan Dasar (RISKESDAS) 2007. Jakarta: Badan Penelitian dan Pengembangan Kesehatan Kementrian Kesehatan Republik Indonesia;2008.

3. Kasman. Faktor-faktor yang berhubungan dengan kejadian diare pada balita di puskesmas air dingin Kecamatan Koto Tangah Kota Padang Sumatera Barat [minor thesis]. Medan; Universitas Sumatera Utara; 2004.

4. Subdit Pengendalian Diare dan Infeksi Saluran Pencernaan Kemenkes RI. Pengendalian Diare di Indonesia. Buletin Jendela Data dan Informasi Kesehatan. 2011:2(2);19-25.

5. Setya N. Faktor-faktor yang berhubungan dengan diare pada anak umur 6$\urcorner-24$ bulan. Banda Aceh: Universitas Syiah Kuala; 2008.

6. Wijayanti W. Hubungan antara pemberian ASI eksklusif dengan angka kejadian diare pada bayi umur 0-6 bulan di puskesmas Gilingan Kecamatan Banjarsari Surakarta [minor thesis]. Surakarta: Universitas Sebelas Maret; 2010.

7. Diwati NG. Hubungan pemberian ASI eksklusif terhadap kejadian diare pada bayi 0-6 bulan di Puskesmas Kecamatan Duren Sawit Jakarta Timur [minor thesis]. Jakarta: Universitas Pembangunan Nasional “Veteran” Jakarta; 2011.

8. Tumbelaka AR, Karyanti MR. Air susu ibu dan pengendalian infeks. Depok: Ikatan Dokter Anak Indonesia; 2013.

9. Departemen Kesehatan Republik Indonesia. Strategi Nasional Sanitasi Total Berbasis Masyarakat. Jakarta: Departemen Kesehatan Republik Indonesia; 2008.

10. Departemen Kesehatan Republik Indonesia. Keputusan Menteri Kesehatan Republik Indonesia Tentang Syarat-Syarat dan Pengawasan Kualitas Air Minum. Jakarta: Departemen Kesehatan Republik Indonesia; 2002. 
11. Direktorat Jenderal Lingkungan Pengendalian Penyakit Menular \& Penyehatan Lingkungan. Pedoman Pemberantasan Penyakit Diare. Jakarta: Direktorat Jenderal Pengendalian Penyakit Menular \& Penyehatan Lingkungan; 2005.

12. Fandiarta AR. Pengaruh faktor sanitasi air minum dan jamban keluarga terhadap kejadian diare pada balita di Desa Sayang dan Desa Cibeusi Kecamatan Jatinangor. Bandung: Universitas Padjadjaran; 2010.

13. Direktorat Jenderal P2PL. Profil Pengendalian dan Penyehatan Lingkungan Tahun 2011. Jakarta: Kementrian Kesehatan Republik Indonesia; 2012.

14. Cairncross S, Boisson S, Bostoen K, Curtis $\mathrm{V}$, Fung IC, et al. Water sanitation and hygiene for the prevention of diarrhoea. Int J Epidemiol. 2010;39:(Suppl1):193-205.

15. Departemen Kesehatan Republik Indonesia. Strategi Nasional Peningkatan Pemberian ASI tahun 2001-2005. Jakarta: Departemen Kesehatan Republik Indonesia ; 2001.

16. Adisasmito W. Faktor risiko diare pada bayi dan balita di Indonesia: systematic review penelitian akademik bidang kesehatan masyarakat. Makara Kesehatan. 2007;11(1):1-10.

17. WHO. Assesing microbial safety of drinking water. [Online Journal] 2012 [cited 2012 May 12]. Available from: http://www.who. int/water_sanitation_health. 